\title{
Optical and Surface Properties of Nanostructured ZnO Semiconductor Thin Films Synthesized by RF Magnetron Sputtering
}

\author{
RF Magnetron Siçratma ile Sentezlenen Nano Yapılı ZnO Yartiletken Ince Filmlerin Optik \\ ve Yüzey Özellikleri
}

\author{
Volkan ŞENAY* \\ Department of Opticianry, Bayburt University, 69000, Turkey
}

• Geliş tarihi / Received: 13.03.2019 • Düzeltilerek geliş tarihi / Received in revised form: 16.08.2019 • Kabul tarihi / Accepted: 23.08 .2019

\begin{abstract}
In this research, $\mathrm{ZnO}$ thin films were deposited on glass microscope slides in three separate experiments with RF input powers of $50 \mathrm{~W}, 100 \mathrm{~W}$ and $125 \mathrm{~W}$ by means of RF magnetron sputtering technique. Each deposition process was conducted for 30 minutes. Spectroscopic reflectometer, UV-VIS spectrophotometer and atomic force microscope (AFM) were used to examine the effect of sputtering power on the optical and surface properties of the produced thin films. The level of reflectivity and transparency, refractive index and band gap energy values as well as surface homogeneity and roughness were observed to rely on the RF input power. The optical band gap energy values were about 3.83-3.87 eV. The produced highly transparent $\mathrm{ZnO}$ thin films can be used in various optoelectronic devices and future transparent conductive electrode implementations.
\end{abstract}

Anahtar kelimeler: RF magnetron sputtering, Surface properties, Optical properties, ZnO thin films

$\ddot{O}_{z}$

Bu araştırmada, RF magnetron sıçratma tekniği ile $50 \mathrm{~W}, 100 \mathrm{~W}$ ve $125 \mathrm{~W}$ RF güçleri ile üç ayrı deneyde ZnO ince filmler cam mikroskop lamlarının üzerine biriktirilmiştir. Her biriktirme işlemi 30 dakika sürdürülmüştür. Spektroskopik reflektometre, UV-VIS spektrofotometre ve atomik kuvvet mikroskobu (AFM), üretilen ince filmlerin optik ve yüzey özellikleri üzerine sıçratma gücünün etkisini incelemek için kullanılmıştır. Yansıtma ve geçirgenlik düzeyi, kırılma indisi ve yasak enerji aralığ değerleri ile yüzey homojenliği ve pürüzlülüğün RF gücüne bă̆lı olduğu bulunmuştur. Yasak enerji aralı̆̆ yaklaşı 3.83-3.87 eV civarındadır. Üretilen son derece şeffaf ZnO ince filmler, çeşitli optoelektronik cihazlar ve gelecekteki şeffaf iletken elektrot uygulamalarında kullanılabilir.

Keywords: RF magnetron sıçratma, Yüzey özellikleri, Optik özellikler, ZnO ince filmler 


\section{Introduction}

Transparent conducting oxides (TCOs) have been an attractive research topic in recent years since they are being used in the production of optoelectronic devices (e.g. touch screens, LCDs, solar cells and LEDs) (Lee et al., 2003; Muchuweni et al., 2016a,b). TCOs are required to show both high electrical conductivity along with high optical transparency in the visible region (Muchuweni et al., 2017). Nowadays, indium tin oxide (ITO) is the most common one among TCO materials (Sathiaraj, 2008; Srivastava and Kumar, 2013). Nevertheless, ITO has a number of drawbacks such as high cost, scarcity and toxicity; thus, there has been an effort to develop alternatives for ITO (Srivastava and Kumar, 2013). Moreover, when exposed to a hydrogen plasma environment, the optical and electrical properties of ITO are negatively affected (Lee et al., 2003). In this respect, it has been revealed that II-VI compound semiconductor zinc oxide $(\mathrm{ZnO})$ may be an alternative material for ITO as it has unique optical and electrical properties, high chemical and mechanical stability, absence of toxicity, abundance in nature of $\mathrm{Zn}$ (Bedia et al., 2015; Muchuweni et al., 2016c; Sahal et al., 2008; Zahirullah et al., 2018). ZnO exhibits n-type conductivity. It has a direct wide band gap energy of $3.37 \mathrm{eV}$ and large exciton binding energy of 60 $\mathrm{meV}$ at room temperature (Bedia et al., 2015; Panda and Jacob, 2012; Shinde et al., 2012; Zahirullah et al., 2018). As this semiconductor has a direct wide band gap, it is optically transparent for a large wavelength range in the solar spectrum (Bedia et al., 2015; Panda and Jacob, 2012). Depending on the growth conditions, the band gap energy of $\mathrm{ZnO}$ can be adjusted. By doing so, $\mathrm{ZnO}$ turns into a more usable material for optoelectronic applications (Güney and Ertarğın, 2015). Efficient emission at room temperature can be ensured due to its high exciton binding energy (Zahedi et al., 2014).

Although there are several studies on $\mathrm{ZnO}$, it still holds its popularity among researchers (Özgür et al., 2019). The results show that thin films of $\mathrm{ZnO}$ can be used in varistors (Ezhilvalavan and Kutty, 1997), gas sensors (Xu et al.,2000), solar cell transparent contact fabrication (Bhatt et al., 1997), ultraviolet light-emitting devices (Deng et al., 2013), ultraviolet photodetectors (Soylu and Yakuphanoğlu, 2016), piezoelectric transducers and surface acoustic wave (SAW) devices (Nagayasamy et al., 2013), etc. Regarding its synthesis, $\mathrm{ZnO}$ thin films have been produced by several thin film manufacturing techniques including PLD (Sans et al., 2004), RF magnetron sputtering (Yang et al., 2008), CVD (Kashiwaba et al., 2000), spray pyrolysis (Paraguay et al., 1999), electrodeposition (Cembrero et al., 2004), sol-gel process (Kamalasanan and Chandra, 1996), etc. Among these fabrication processes, the $\mathrm{RF}$ magnetron sputtering has emerged as a method which is one of the most promising processing routes since it is especially provides economical production of thin, transparent and homogeneous oxide films on various substrates. It enables the adjustment of the refractive index and thickness of the film by changing deposition parameters. In this study, $\mathrm{ZnO}$ thin films were manufactured by RF magnetron sputtering method and considered the impact of RF sputtering power on optical and surface properties.

\section{Experimental details}

In the present study, three $\mathrm{ZnO}$ thin films were deposited on $75 \mathrm{~mm} \times 25 \mathrm{~mm} \times 1 \mathrm{~mm}$ glass microscope slides in three separate experiments with different RF powers of $50 \mathrm{~W}, 100 \mathrm{~W}$ and 125 $\mathrm{W}$ by means of RF magnetron sputtering technique at room temperature. There are many studies in literature where RF input power value is between $50 \mathrm{~W}$ and $300 \mathrm{~W}$. The values chosen within them can be arbitrary. In order not to cause high heating of the target and to have more stable conditions during deposition, maximum $125 \mathrm{~W}$ RF power was applied to the target in this study A $\mathrm{ZnO}$ target was used as source material for all deposition processes. The diameter of the target was $50 \mathrm{~mm}$ while its thickness was $3 \mathrm{~mm}$. The target was powered through a RF power supply operating at a frequency of $13.56 \mathrm{MHz}$. The substrate was directly fixed on a substrate holder positioned at $40 \mathrm{~mm}$ away from the target in all cases. For all depositions, sputtering chamber was evacuated down to $1 \times 10^{-2}$ Torr by using a mechanical pump and then filled with $99.99 \%$ purity $\mathrm{Ar}$ gas. Chamber pressure was sustained to be $6 \times 10^{-2}$ Torr during deposition process. Each deposition process was carried out for $30 \mathrm{~min}$. Only top surfaces of the substrates were coated with $\mathrm{ZnO}$. After being deposited, the samples were taken out for characterization. Deposition parameters are summarized in Table 1. The ZNO thin films deposited at the RF powers of 50, 100, and $125 \mathrm{~W}$ were labeled as ZNO50, ZNO100 and ZNO125, respectively.

The crystalline structure of the produced $\mathrm{ZnO}$ thin films was examined in the $2 \theta$ range of $20^{\circ}-80^{\circ}$ by using an X-ray diffractometer (PANalytical Empyrean) with monochromated $\mathrm{CuK} \alpha$ radiation $(\lambda=1.54056 \AA)$. 
Table 1. Sputtering parameters of $\mathrm{ZnO}$ thin films

\begin{tabular}{llll}
\hline RF power $(\mathrm{W})$ & Substrate to target distance $(\mathrm{mm})$ & Working pressure (Torr) & Time (min) \\
\hline $50,100,125$ & 40 & $6 \times 10^{-2}$ & 30 \\
\hline
\end{tabular}

The reflectance spectra were obtained in the wavelength range of $400-1000 \mathrm{~nm}$ by a spectroscopic reflectometer (Filmetrics F20 Thin Film Analyzer). The film thickness ( $t$ ) and spectral distribution of refractive index (n) were extracted through the spectral analysis of reflectance. The optical transmittance and absorbance spectra were recorded at normal incidence of light with a double beam UV-VIS spectrophotometer (UNICO 4802). The spectral region observed was 300-1100 $\mathrm{nm}$. The optical energy band gap values were then derived from the absorbance spectra data via Tauc's method. In order to illustrate the surface topography, threedimensional images were taken over a scale of 4 $\mu \mathrm{m} \times 4 \mu \mathrm{m}$ in non-contact mode by using an AFM
(Ambios Q-Scope). The root mean square (RMS) roughness (Rq) parameter was acquired over the entire images.

\section{Results and discussion}

Figure 1 shows the XRD patterns of the produced $\mathrm{ZnO}$ thin films. X-ray diffraction study confirms that the synthesized material is $\mathrm{ZnO}$ with hexagonal wurtzite crystal structure and the entire diffraction peaks are in agreement with the standard JCPDS data (card No. 36-1451). No other undesired peaks were observed due to secondary phases or impurity phases within the detection limit of the X-ray diffractometer.

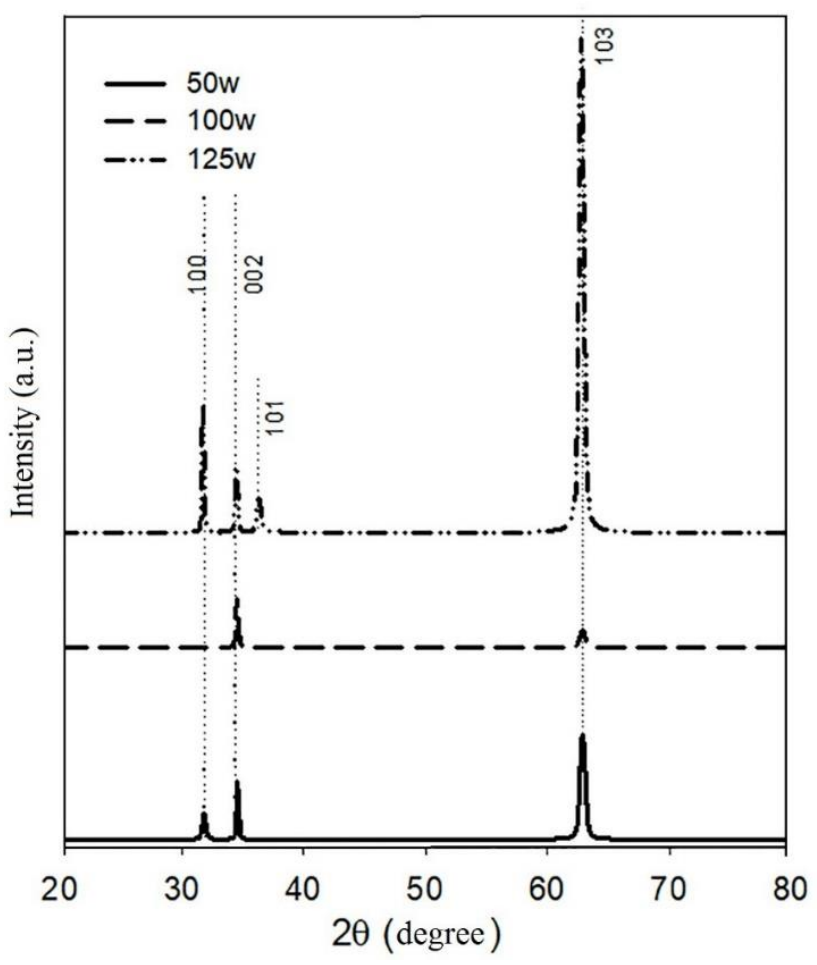

Figure 1. XRD patterns of the produced $\mathrm{ZnO}$ thin films

The reflectance spectra of the produced $\mathrm{ZnO}$ thin films are presented in Figure 2. The intensity of the reflected light varies with wavelength which depends on the film thickness and the optical constants ( $\mathrm{n}$ and $\mathrm{k}$ ) of the film. The experimentally obtained reflectance spectrum is compared with a theoretical reflection spectrum derived from the database of optical constants, and the thickness and optical constants are optimized until the best fit between the curves is achieved. The software gives the value of thickness and spectral distribution of optical constants of the film together with a goodness of fit (GOF) value. The film thickness values obtained from the spectroscopic reflectometry measurements are 30,39 and $67 \mathrm{~nm}$ for the corresponding RF powers $50 \mathrm{~W}, 100 \mathrm{~W}$ and 125 $\mathrm{W}$, respectively. The RF power applied to the 
target and the obtained film thickness may not be directly proportional (Aznilinda et al, 2012). With the increase in RF power, the kinetic energy of the sputtered particles also increases, which then leads to the increase of the sputtering yield. In other words, at the higher RF power, the bombarding ions have higher kinetic energy due to momentum transfer, so that more atoms will be sputtered (Hwang et al., 2003). The sputtered atoms get higher energy at higher RF power and results the higher $\mathrm{ZnO}$ molecules arriving at substrate compare at lower RF power deposition and it contributes to the film growth (Yu et al., 2005). This situation is more prominent here after $100 \mathrm{~W}$. It is also found that produced relatively thicker $\mathrm{ZnO}$ films exhibit higher reflectance than thinner $\mathrm{ZnO}$ films in the observed wavelength range.

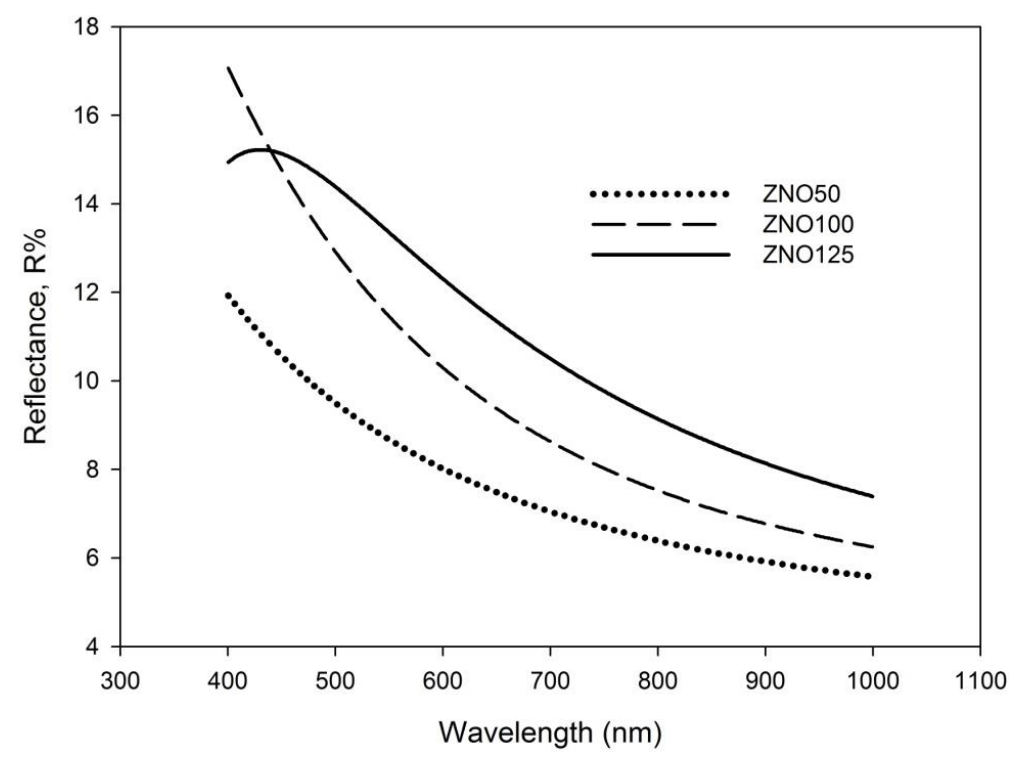

Figure 2. The reflectance spectra of the produced $\mathrm{ZnO}$ thin films

The spectral distributions of refractive index of the produced $\mathrm{ZnO}$ thin films are presented in Figure 3. The result is in good agreement with relevant literature (Gümüş et al., 2006; Çağlar et al., 2009). Refractive index measurements were realized using Cauchy model. Cauchy equation for the refractive index is given by:

$$
\mathrm{n}(\lambda)=\mathrm{A}_{\mathrm{n}}+\mathrm{B}_{\mathrm{n}} / \lambda^{2}+\mathrm{Cn} / \lambda^{4} \text { and } \mathrm{k}(\lambda)=0
$$

where $A_{n}, B_{n}$ and $C_{n}$ are the fitting parameters used in Cauchy model. As shown in the figure, the refractive index strongly depends on the RF power. The increment of deposition rate with the increasing RF power first levels the refractive index value due to an increase of film packing density. Further rise of RF power brings about a strong decrease of refractive index and density.

The transmittance and absorbance spectra of the produced $\mathrm{ZnO}$ thin films are presented in Fig. 4. Optical transmittance spectrum shows that the films have high transmission in the visible region. This observation is in line with relevant literature (Golovynskyi et al., 2018). The absence of optical interference fringes in the spectrum indicates that the $\mathrm{ZnO}$ films are thin (Cruz et al., 2018). High transmittance in the visible region is typical of transparent conductive oxides. However, the transmittance decreased with the increasing film thickness. In relatively thicker films, more states are available for the photons to be absorbed. This observation also confirms relevant literature (Shariffudin et al., 2012). In transparent metal oxides, ratio of metal to oxygen also determines the level of transparency. A metal rich film often shows less transparency (Çăglar et al., 2006). It is found out that the absorbance of the $\mathrm{ZnO}$ films is high at short wavelengths $(\lambda<380 \mathrm{~nm})$ and low at longer wavelengths. Hence the films have potential application in fabrication of solar cells (Ezenwa, 2012). As the RF power increases absorption decreases because of inverse relation between transmission and absorption. It can be also seen that the absorption edge moves towards a higher wavelength with the increasing RF power.

The optical band gap energy of the produced $\mathrm{ZnO}$ thin films can be obtained from the relationship between the optical absorption coefficient and the absorbance. 


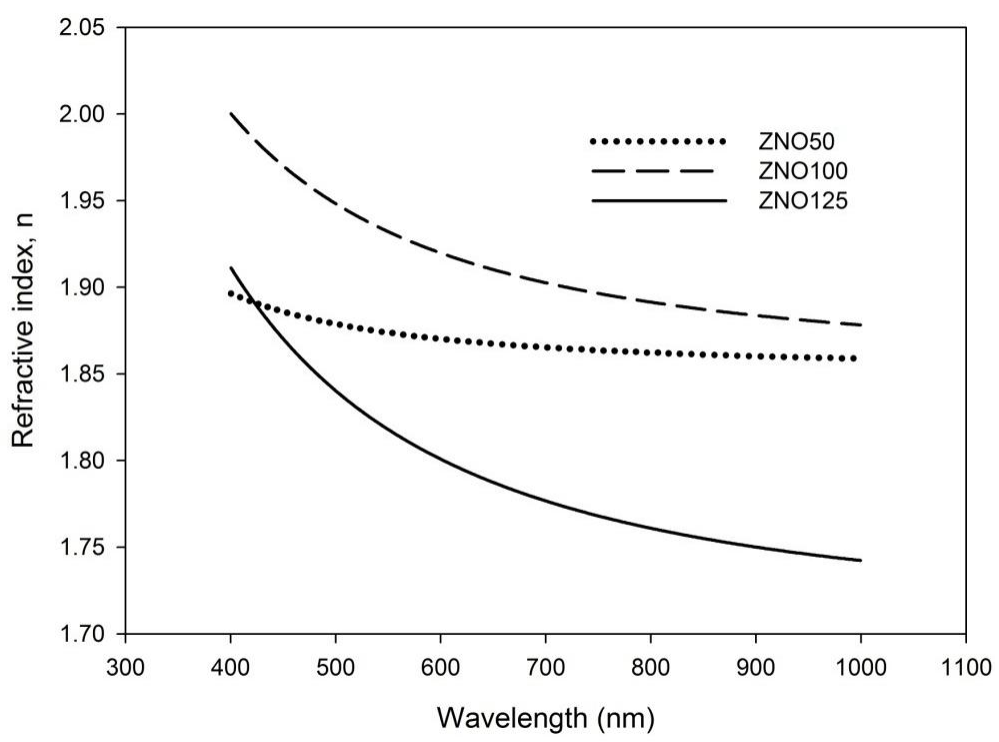

Figure 3. The spectral distributions of refractive index of the produced $\mathrm{ZnO}$ thin films

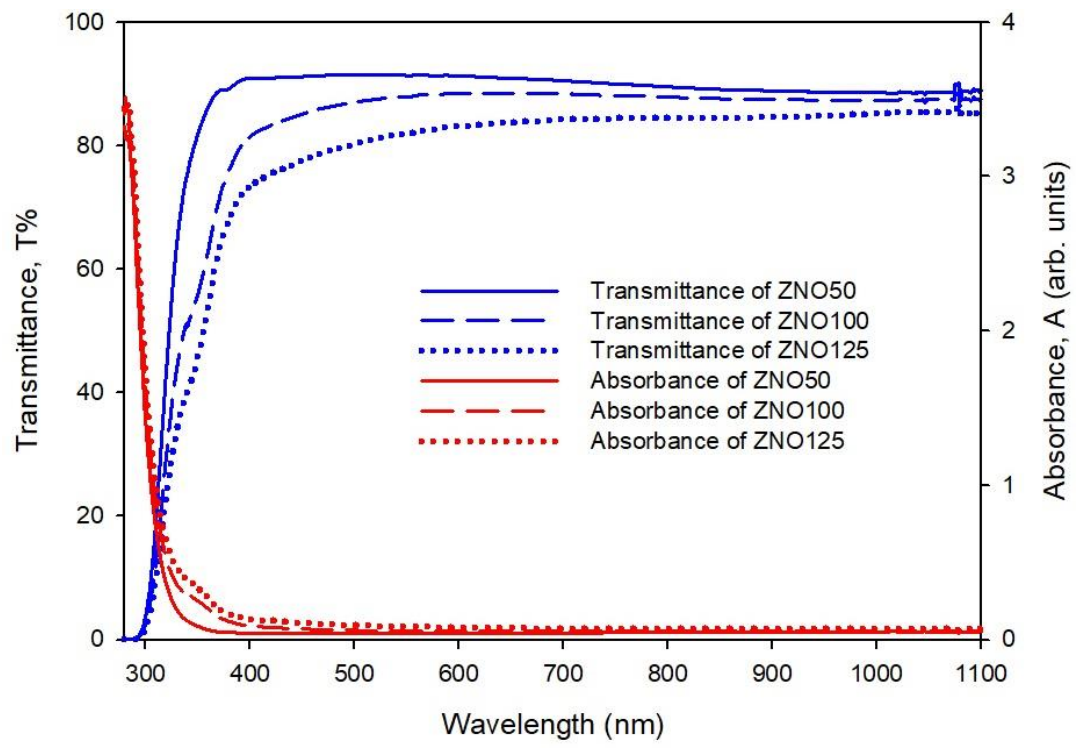

Figure 4. The transmittance and absorbance spectra of the produced $\mathrm{ZnO}$ thin films

The absorption coefficient $\alpha$ near the absorption edge is given by $\alpha=2.303 \mathrm{~A} / \mathrm{t}$ where $\mathrm{t}$ is film thickness. For a semiconductor with a direct band gap, the optical band gap can be expressed by the Tauc method (Tauc et al., 1966):

$(\alpha h \gamma)^{2}=A\left(h \gamma-E_{g}\right)$

where $\mathrm{A}$ is a proportional constant, $\mathrm{h} \gamma$ is the photon energy of the incident photon, and $E_{g}$ is the optical band gap energy. The optical band gap energy is obtained by extrapolating the tangential line to the photon energy axis in the plot of $(\alpha h \gamma)^{2}$ versus $h \gamma$, as shown in Figure 5. The optical band gap values obtained via the Tauc method are 3.87, 3.84 and $3.83 \mathrm{eV}$ for the corresponding RF powers $50 \mathrm{~W}, 100 \mathrm{~W}$ and 125
$\mathrm{W}$, respectively. These values are in parallel with related literature (Mursal et al., 2018).

The 3D AFM images of the produced $\mathrm{ZnO}$ thin films are presented in Figure 6. The produced $\mathrm{ZnO}$ film surfaces show mount-like structures. ZNO50 has the most homogenous surface without pores and the smallest grains. When RF power increases from $50 \mathrm{~W}$ to $100 \mathrm{~W}$, grains become larger in both lateral and vertical directions. ZNO125 has a more homogenous surface than ZNO100. The grain size of ZNO125 is lower than that of ZNO100. The RMS (Rq) values obtained from the AFM measurements are 1.08, 9.04 and $4.11 \mathrm{~nm}$ for the corresponding RF powers $50 \mathrm{~W}$, $100 \mathrm{~W}$ and $125 \mathrm{~W}$, respectively. 


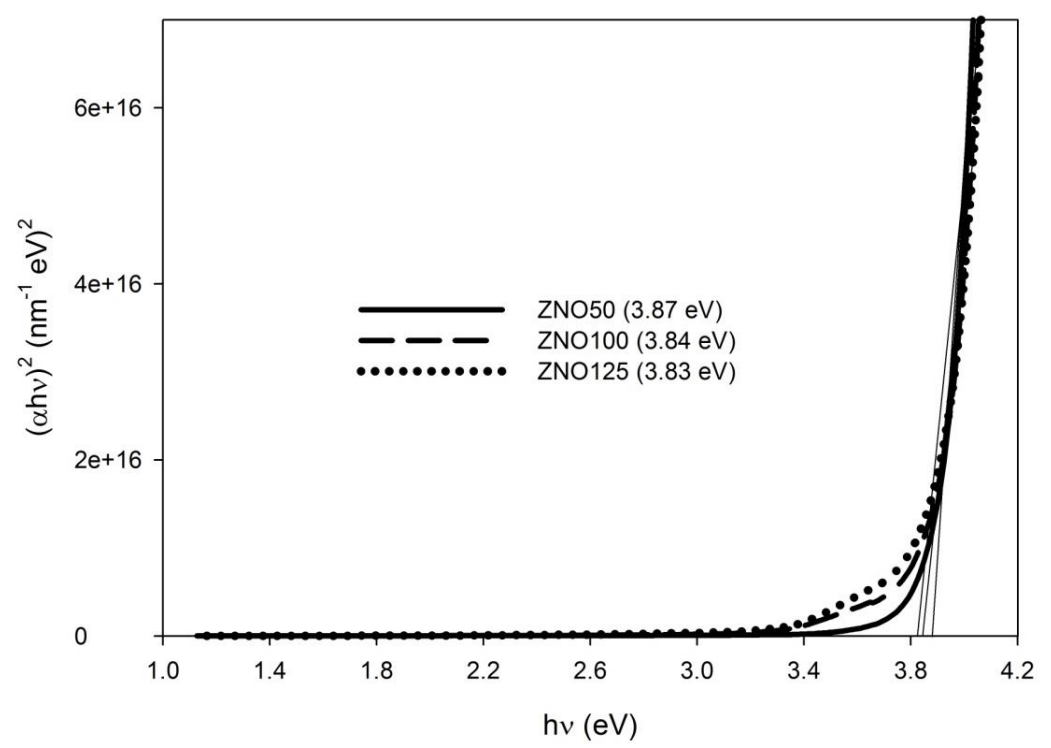

Figure 5. Plots of $(\alpha h v)^{2}$ vs. $h v$ to estimate the Eg values of the produced $\mathrm{ZnO}$ thin films

The surface roughness can affect optical properties of thin films and depends not only on grain size but also on the number, shape and orientation of grains. As a result, the RMS roughness of the produced thin films increases with the decreasing surface homogeneity due to a textured surface formation with larger pyramidal structures. This result is partly similar to the observation reported in the relevant literature (Silva et al., 2014).

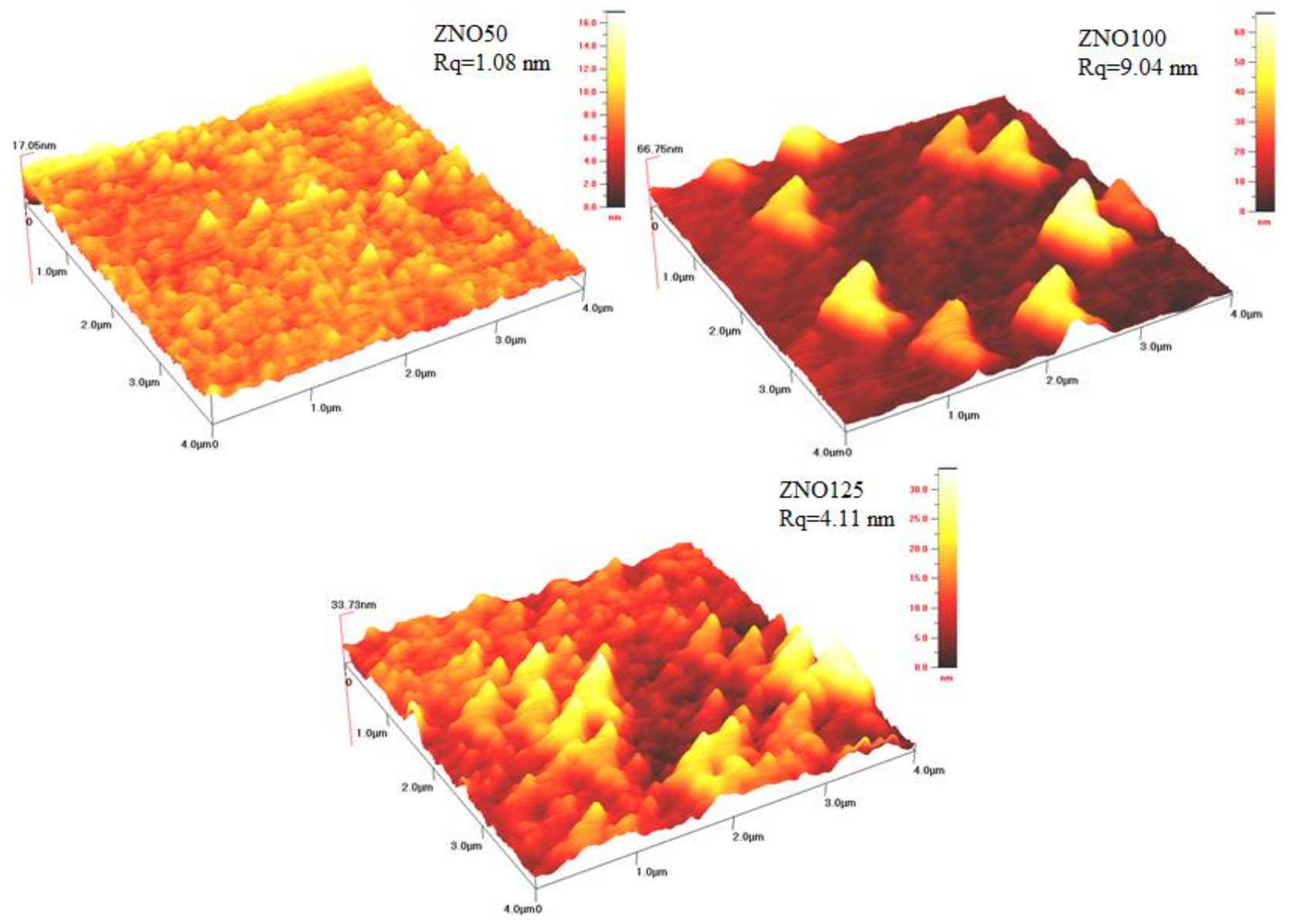

Figure 6. 3D AFM images of the produced $\mathrm{ZnO}$ thin films. 


\section{Conclusion}

In conclusion, $\mathrm{ZnO}$ thin films having different thickness values were produced on glass substrates in three separate experiments with RF powers of $50 \mathrm{~W}, 100 \mathrm{~W}$ and $125 \mathrm{~W}$ by means of RF magnetron sputtering technique. The produced $\mathrm{ZnO}$ thin films were investigated by several instrumentation techniques. According to the current results, deposition rate increases with the increasing RF power. The produced films are highly transparent in the visible region. Relatively thicker $\mathrm{ZnO}$ films exhibit higher absorption and reflection. The high UV absorption of $\mathrm{ZnO}$ can be used in various areas such as cosmetics, paints, and varnishes. The refractive index values show normal dispersion and decrease with the increasing wavelength. It is observed that the refractive index value of $\mathrm{ZnO}$ films can be tuned by changing RF power. The optical band gap energy values are about 3.83-3.87 eV. A $\mathrm{ZnO}$ thin film having a smooth and homogenous surface can be obtained with a relatively low RF power such as $50 \mathrm{~W}$.

\section{References}

Aznilinda, Z., Herman, S. H., and Rusop, M., 2012. Physical characteristic of room-temperature deposited $\mathrm{TiO} 2$ thin films by RF magnetron sputtering at different RF power. IEEE Symposium on Humanities, Science and Engineering Research, June 2012, pp. 685-689.

Bedia, A., Bedia, F.Z., Aillerie, M., Maloufi, N. and Benyoucef, B., 2015. Morphological and optical properties of $\mathrm{ZnO}$ thin films prepared by spray pyrolysis on glass substrates at various temperatures for integration in solar cell. Energy Procedia, 74, 529-538.

Bhatt, R., Sankaranarayanan, H., Ferekides, C. and Morel, D., 1997. The dependence of reactively sputtered $\mathrm{ZnO}$ electronic properties on growth parameters for use as buffer layers in CuIn/sub $\mathrm{x} / \mathrm{Ga} / \mathrm{sub} 1-\mathrm{x} / \mathrm{Se} / \mathrm{sub} 2 /$ solar cells. Photovoltaic Special lists Conference, 1997.

Cembrero, J., Elmanouni, A., Hartiti, B., Mollar, M. and Marí, B., 2004. Nanocolumnar ZnO films for photovoltaic applications. Thin Solid Films, 451-452, 198-202.

Cruz, M.R.A., Ceballos-Sanchez, O., LuévanoHipólito, E. and Torres-Martínez, L.M., 2018. $\mathrm{ZnO}$ thin films deposited by $\mathrm{RF}$ magnetron sputtering: Effects of the annealing and atmosphere conditions on the photocatalytic hydrogen production. International Journal of Hydrogen Energy, 43(22), 10301-10310.
Çaglar, M., Caglar, Y. and Ilican, S., 2006. The determination of the thickness and optical constants of the $\mathrm{ZnO}$ crystalline thin film by using envelope method. Journal of Optoelectronics and Advanced Materials, 8(4), 1410-1413.

Deng, R., Yao, B., Li, Y.F., Xu, Y., Li, J.C, Li, B.H., Zhang, Z.Z., Zhang, L.G., Zhao, H.F. and Shen, D.Z., 2013. Ultraviolet electroluminescence from $\mathrm{n}-\mathrm{ZnO} / \mathrm{p}-\mathrm{NiO}$ heterojunction light-emitting diode. Journal of Luminescence, 134, 240-243.

Ezenwa, I.A., 2012. Synthesis and optical characterization of zinc oxide thin film. Research Journal of Chemical Sciences, 2(3), 26-30.

Ezhilvalavan, S., and Kutty, T.R.N., 1997. Effect of antimony oxide stoichiometry on the nonlinearity of zinc oxide varistor ceramics. Materials Chemistry and Physics, 49(3), 258269.

Gümüş, C., Özkendir, O.M., Kavak, H., and Ufuktepe, Y., 2006. Structural and optical properties of zinc oxide thin films prepared by spray pyrolysis method. Journal of Optoelectronics and Advanced Materials, 8(1), 299-303.

Güney, H. and Ertarğın, M.E., 2015. Effective annealing of $\mathrm{ZnO}$ thin films grown by three different SILAR processes. Eastern Anatolian Journal of Science, 1(1), 20-24.

Golovynskyi, S., Ievtushenko, A., Mamykin, S., Dusheiko, M., Golovynska, I., Bykov, O., Olifan, O., Myroniuk, D., Tkach, S. and Qu, J., 2018. High transparent and conductive undoped $\mathrm{ZnO}$ thin films deposited by reactive ion-beam sputtering. Vacuum, 153, 204-210.

Hwang, D.K., Bang, K.H., Jeong, M.C., and Myoung, J.M., 2003. Effects of RF power variation on properties of $\mathrm{ZnO}$ thin films and electrical properties of $\mathrm{p}-\mathrm{n}$ homojunction. Journal of Crystal Growth, 254(3-4), 449-455.

Kamalasanan, M.N. and Chandra, S., 1996. Sol-gel synthesis of $\mathrm{ZnO}$ thin films. Thin Solid Films, 288(1-2), 112-115.

Kashiwaba, Y., Katahira, F., Haga, K., Sekiguchi, T. and Watanabe, H., 2000. Hetero-epitaxial growth of $\mathrm{ZnO}$ thin films by atmospheric pressure CVD method. Journal of Crystal Growth, 221(1-4), 431-434.

Lee, J.H.., Ko, K.H. and Park, B.O., 2003. Electrical and optical properties of $\mathrm{ZnO}$ transparent conducting films by the sol-gel method. Journal of Crystal Growth, 247(1-2), 119-125. 
Muchuweni, E., Sathiaraj, T. and Nyakotyo, H., 2016a. Effect of gallium doping on the structural, optical and electrical properties of zinc oxide thin films prepared by spray pyrolysis. Ceramics International, 42(8), 10066-10070.

Muchuweni, E., Sathiaraj, T. and Nyakotyo, H., $2016 \mathrm{~b}$. Low temperature synthesis of radio frequency magnetron sputtered gallium and aluminium codoped zinc oxide thin films for transparent electrode fabrication. Applied Surface Science, 390, 570-577.

Muchuweni, E., Sathiaraj, T. and Nyakotyo, H. 2016c., Physical properties of gallium and aluminium co-doped zinc oxide thin films deposited at different radio frequency magnetron sputtering power. Ceramics International, 42(15), 1770617710 .

Muchuweni, E., Sathiaraj, T. and Nyakotyo, H., 2017. Synthesis and characterization of zinc oxide thin films for Optoelectronic Applications. Heliyon, 3(4), e00285.

Mursal, Irhamni, Bukhari, and Jalil, Z., 2018. Structural and optical properties of zinc oxide $(\mathrm{ZnO})$ based thin films deposited by sol-gel spin coating method. Journal of Physics: Conference Series, December 2018, p.1-7.

Nagayasamy, N., Gandhimathination, S. and Veerasamy, V., 2013. The Effect of ZnO Thin Film and Its Structural and Optical Properties Prepared by Sol-Gel Spin Coating Method. Open Journal of Metal, 3(02), 8-11.

Özgür, M., Pat, S., Mohammadigharehbagh, R., Musaoğlu, C., Demirkol, U., Elmas, S., Özen, S. and Korkmaz, Ş., 2019. Sn doped ZnO thin film deposition using thermionic vacuum arc technique. Journal of Alloys and Compounds, 774, 1017-1023.

Panda, S.K. and Jacob, C. 2012., Preparation of transparent $\mathrm{ZnO}$ thin films and their application in UV sensor devices. Solid-State Electronics, $73,44-50$.

Paraguay, F.D, Estrada, W.L., Acosta, D.R.N., Andrade, E. and Miki-Yoshida, M., 1999. Growth, structure_and optical characterization of high quality $\mathrm{ZnO}$ thin films obtained by spray pyrolysis. Thin Solid Films, 350(1-2), 192-202.

Sahal, M., Hartiti, B., Ridah, A., Mollar, M. and Mari, B., 2008. Structural, electrical and optical properties of $\mathrm{ZnO}$ thin films deposited by solgel method. Microelectronics Journal, 39(12), $1425-1428$.

Sans, J.A., Segura, A., Mollar, M. and Marí, B., 2004. Optical properties of thin films of $\mathrm{ZnO}$ prepared by pulsed laser deposition. Thin Solid Films, 453-454, 251-255.

Sathiaraj, T.S., 2008. Effect of annealing on the structural, optical and electrical properties of ITO films by RF sputtering under low vacuum level. Microelectronics Journal, 39(12), 14441451.

Shinde, S.S., Shinde, P.S., Oh, Y.W., Haranath, D., Bhosale, C.H. and Rajpure, K.Y., 2012. Structural, optoelectronic, luminescence and thermal properties of Ga-doped zinc oxide thin films. Applied Surface Science, 258(24), 99699976.

Silva, É.P.D., Chaves, M., Durrant, S.F., Lisboa-Filho, P.N. and Bortoleto, J.R.R., 2014. Morphological and electrical evolution of $\mathrm{ZnO}: \mathrm{Al}$ thin filmsdeposited by RF magnetron sputtering onto glass substrates. Materials Research, 17(6), 1384-1390.

Shariffudin, S.S., Salina, M., Herman, S.H. and Rusop, M.,2012. Effect of film thickness on structural, electrical, and optical properties of sol-gel deposited layer-by-layer $\mathrm{ZnO}$ nanoparticles. Transactions on Electrical and Electronic Materials, 13(2), 102-105.

Soylu, M. and Yakuphanoglu, F., 2016. Fabrication and characterization of light-sensing device based on transparent $\mathrm{ZnO}$ thin film prepared by sol-gel. Optik, 127(20), 8479-8486.

Srivastava, A.K. and Kumar, J., 2013. Effect of zinc addition and vacuum annealing time on the properties of spin-coated low-cost transparent conducting 1 at $\% \mathrm{Ga}-\mathrm{ZnO}$ thin films. Science and Technology of Advanced Materials, 14(6), 065002.

Tauc, J., Grigorovici, R. and Vancu, A., 1966. Optical properties and electronic structure of amorphous germanium. Physica Status Solidi (b), 15(2), 627-637.

Xu, J., Pan, Q., Shun, Y. and Tian, Z., 2000. Grain size control and gas sensing properties of $\mathrm{ZnO}$ gas sensor. Sensors and Actuators B: Chemical, 66(1-3), 277-279.

Yang, P.F., Wen, H.C., Jian, S.R., Lai, Y.S., Wu, S. and Chen, R.S., 2008. Characteristics of $\mathrm{ZnO}$ thin films prepared by radio frequency magnetron sputtering. Microelectronics Reliability, 48(3), 389-394.

Yu, X., Ma, J., Ji, F., Wang, Y., Zhang, X., Cheng, C., and Ma, H., 2005. Effects of sputtering power on the properties of $\mathrm{ZnO}$ : Ga films deposited by r.f. magnetron-sputtering at low temperature. Journal of Crystal Growth, 274(3-4), 474-479. 
Zahedi, F., Dariani, R.S. and Rozati, S.M, 2014. Structural, optical and electrical properties of $\mathrm{ZnO}$ thin films prepared by spray pyrolysis: effect of precursor concentration. Bulletin of Materials Science, 37(3), 433-439.
Zahirullah, S.S., Immanuel, P., Pravinraj, S., Inbaraj, P.F.H. and Prince, J.J., 2018. Synthesis and characterization of $\mathrm{Bi}$ doped $\mathrm{ZnO}$ thin films using SILAR method for ethanol sensor. Materials Letters, 230, 1-4. 